\title{
STUDIES ON THE GENESIS OF METALLIC MINERAL DEPOSITS OF SHINJO AND YAMAGATA BASINS, NORTHEASTERN JAPAN (II)
}

\author{
Noritsugu Oizumi
}

\section{ORIGIN OF ORE DEPOSITS}

The metallic mineral deposits situated within the Shinjo Basin and the Yamagata Basin include those of gold, silver, copper, lead, zinc, iron sulphides and others. All in all, they amount to more than 300 individual ore deposits, distributed within the granitic Basement rocks and largely, within the earlier and later stages of the Miocene sequence.

These ore deposits are generally hydrothermal in origin, formed by the process of magmatic differentiation. They tend to be concentrated in areas of igneous activity. (McKinstry, 1955). They are remarkably controlled by geologic structures produced by uplift of the Basement, orogenesis accompanied by folding of sedimentary rocks, and volcanic activity. The crushed zones, faults and fissures produced by these processes, served as the passageways for mineralizing solutions and depositional sites of the ore minerals (Emmons, 1948; Lewis, 1955).

The structures present in the area are roughly classified into those produced by the uplift of the granitic Basement and those produced by folding of the sedimentary rocks. Included in the former, are the N-S to NNE-SSW trending axis of the Basement Rise, the major faults parallel to this axis, and the subordinate faults and fissures perpendicular to it. Included in the later are the N-S, NNWSSE trending fold axes, the major faults parallel to these axes, the crushed zone perpendicular to them, and the NE-SW trending tension cracks and crushed zones, within which are abundant E-W trending minor fractures cutting the trend of the fold axes obliquely (Billings, 1962).

These major structures, subordinate structures, and the combination of such structures, served as access to the flow of mineralizing solutions. They also served as access of the intrusions 
Table 3. Number of veins in

\begin{tabular}{c|c|c|c|c|c|c|c|c}
\hline Strike & 80 & 70 & 60 & 50 & 40 & 30 & 20 & $\begin{array}{l}\mathrm{W} \rightarrow \\
10\end{array}$ \\
\hline $\begin{array}{c}\text { Shinjo } \\
\text { basin } \\
\%\end{array}$ & 12 & 9 & 2 & 2 & 1 & 5 & 4 & 3 \\
\hline $\begin{array}{c}\text { Yamagata } \\
\text { basin } \\
\%\end{array}$ & 5.6 & 6.4 & 1.4 & 1.4 & 0.7 & 3.6 & 2.8 & 2.1 \\
\hline $\begin{array}{c}\% \\
\text { both } \\
\text { basin total } \\
9\end{array}$ & 2.7 & 1.6 & 4.3 & 3.2 & 2.7 & 1.6 & 0 & 1.1 \\
\hline
\end{tabular}

of dikes and sheets of "Tertiary granite", dacite, rhyolite and dolerite. With in and around these intrusive bodies are many different kinds of ore deposits (Schneiderhöhn, 1949; Lewis, 1955). Thus, the Nissho, Nakanomata and Kamuro ore deposits of northern Shinjo Basin are all related to the "Tertiary granite", and the ore veins trend parallel to the trend of the dikes of this igneous rock, or perpendicular to them. The Akayama and Shingoro ore deposits of southern Yamagata Basin are related to dacite dikes, and the ore bodies are lenticular in form, with their longer axes trending ENE. The deposit of Daiyama mine in eastern Shinjo Basin and that of Gando mine in eastern Yamagata Basin, occur as veins associated with numerous dolerite dikes. The massive ore deposits of Hotei, Daikoku and Ebisu of Yoshino District, western Yamagata Basin,occur along weak zones elongated along the NNE-SSW direction and parallel to the trend of the axis of the Basement Rise (Cloos. 1939; Lewis, 1955).

The stockwork deposits occur in areas where the major structures and subordinate structures cross each other. This is true in the case of the stockwork deposits of Fukufune, Daio, and Nobezawa of Shinjo Basin, and the Koyama, Honjo, Shuyama and Shirataka of Yamagata Basin. In these ore deposits the most important ore filled fissures making up the stockworks are those trending E-W.

In the Fulkufune mine, the most abundant veinlets are those trending $\mathrm{E}-\mathrm{W}$, and those trending N-S are only next in abundance. In the Daio mine, the most abundant veinlets are those trending $\mathrm{E}-\mathrm{W}$, and this is followed by those trending NW-SE. In the Koyama mine, those trending practically $\mathrm{E}-\mathrm{W}$ (N70W) are also the most 
each directions

\begin{tabular}{c|c|c|c|c|c|c|c|c|c|c}
\hline $\mathrm{N}-\mathrm{S}$ & $\begin{array}{r}\rightarrow \mathrm{E} \\
10\end{array}$ & 20 & 30 & 40 & 50 & 60 & 70 & 80 & $\mathrm{E}-\mathrm{W}$ & Total \\
\hline 0 & 4 & 4 & 1 & 7 & 10 & 27 & 18 & 16 & 15 & 140 \\
0 & 2.8 & 2.8 & 0.7 & 5.0 & 7.1 & 19.3 & 12.8 & 11.4 & 10.7 & 100 \\
\hline 5 & 7 & 12 & 10 & 13 & 15 & 24 & 21 & 23 & 23 & 185 \\
2.7 & 3.8 & 6.5 & 5.4 & 7.0 & 8.1 & 13.0 & 11.4 & 12.4 & 12.4 & 100 \\
\hline 5 & 11 & 16 & 11 & 20 & 25 & 51 & 39 & 39 & 38 & 325 \\
1.5 & 3.3 & 4.9 & 3.3 & 6.8 & 7.7 & 15.7 & 12.0 & 12.0 & 11.7 & 100 \\
\hline
\end{tabular}

abundant, and those trending practically N-S (N20E) are next in abundance. In the Shuyama mine, the $\mathrm{E}-\mathrm{W}$ veinlets are also the most abundant, but other veinlets trend in almost every direction. In the Shirataka mine the NE-SW veinlets are the most abundant, and the E-W and NNW-SSE are only next in abundance. The remarkable abundance of the E-W trending veinlets show that the direction of compression in this region was along the $\mathrm{E}-\mathrm{W}$ direction, at the time of the formation of the fissures filled by the ore veinlets (Lindgren, 1933; Mckinstry, 1942).

The vein type deposits are actually, relatively larger fissures filled with ore. The veins occurring within the granitic rocks of the Basement are those of: Akadakihi of Raidakihi mine and Tenguzawahi of Kamuro mine, eastern Shinjo Basin; the 7 ore veins of Chiyogasawa mine, eastern Yamagata Basin; and the veins of Dainan mine, southeastern Yamagata Basin. All of these veins trend N-S, and parallel to the trend of the Basement axis. Those of: Daiyama mine, and Tengumori mine of eastern Shinjo Basin; the Himezawa ore deposit of eastern Yamagata Basin; and the Asahi and Nishizawa vein of Azuma mine, southern Yamagata Basin, all trend $\mathrm{E}-\mathrm{W}$ and perpendicular to the Basement axis.

The veins filling fissures releated to the uplift of the Basement, but within the sedimentary rocks are those trending N-S and E-W. Those related to the folding of sedimentary rocks are those trending NE-SW and ENE. The former are deposited mainly within the lowermost formation of the Miocene, while the latter are formed within most of the Miocene formations. The NE-SW and ENE trending veins are the most abundant of the vein type deposits, and they are 
Table 4. Showing the relative abundance of ore vein system

\begin{tabular}{l|c|c|c|c|c}
\hline \multicolumn{1}{c|}{ Locality } & $\begin{array}{c}\text { No. of } \\
\text { veins }\end{array}$ & $\begin{array}{c}\text { Most } \\
\text { abundant }\end{array}$ & abundant & Moderate & Scarce \\
\hline $\begin{array}{l}\text { Northern \& eastern } \\
\text { Shinjo Basin }\end{array}$ & 93 & $\pm \mathrm{N} 64 \mathrm{E}$ & $\pm \mathrm{N} 75 \mathrm{E}$ & $\pm \mathrm{E}-\mathrm{W}$ & $\begin{array}{l}\text { N-S or } \\
\pm \mathrm{N} 30 \mathrm{~W}\end{array}$ \\
\hline $\begin{array}{l}\text { Ou Backbone } \\
\text { Range }\end{array}$ & 115 & $\pm \mathrm{N} 66 \mathrm{E}$ & $\pm \mathrm{N} 85 \mathrm{E}$ & $\mathrm{N} 20 \mathrm{E}$ & $\pm \mathrm{N} 20 \mathrm{~W}$ \\
\hline $\begin{array}{l}\text { Gassan-Hayama } \\
\text { Mountainland }\end{array}$ & 92 & $\pm \mathrm{N} 62 \mathrm{E}$ & $\pm \mathrm{N} 85 \mathrm{E}$ & N30-50E & $\pm \mathrm{N} 20 \mathrm{~W}$ \\
\hline $\begin{array}{l}\text { Over-all Shinjo \& } \\
\text { Yamagata Basins }\end{array}$ & 300 & $\pm \mathrm{N} 64 \mathrm{E}$ & N70-90E & N 40-50W & $\pm \mathrm{N} 20 \mathrm{~W}$ \\
\hline
\end{tabular}

the most important ore deposits within the two basins. The N-S and NW-SE trending fissures, within the upper formations of the Miocene, are very rarely filled with ore, because extreme pressure produced by the E-W lateral compression retarded the passage of minerlaizing solutions along these routes (Newhouse, 1931).

The 140 ore veins of Shinjo Basin and the 185 ore veins of Yamagata Basin, lumped all together, strike ENE-WSW, which is also the strike of most of the veins taken individually. This structural trend makes an angle of about 60 degrees with the N-S trend of the major structural line of the region.

Accordingly, in the Shinjo Basin, those veins striking from $\mathrm{N} 60 \mathrm{E}$ to $\mathrm{N} 80 \mathrm{~W}$ comprise $62.8 \%$ of the total number of veins within the basin. Among these, the N60E trending veins, which comprise $19.3 \%$, are the most abundant. In the Yamagata Basin, those veins striking from $\mathrm{N} 50 \mathrm{E}$ to $\mathrm{E}-\mathrm{W}$ comprise $57.3 \%$ of the total number of veins within it. Among these, the N60E striking veins, which comprise $13.0 \%$ are the most abundant. The N80E and the $\mathrm{E}-\mathrm{W}$ striking veing each comprise $12.4 \%$ of the total number of veins in the basin.

The veins occurring most scarcely are those striking N-S and $\mathrm{N} 40 \mathrm{~W}$, in the Shinjo Basin and those striking N20W and N-S to N10W, in the Yamagata Basin. Considering both basins, these trends amount ot NNW-SSE. Thus, it appears that the direction of the most abundant veins and that of the scarsest veins are perpendicular to each other.

As shown by the result of stereographic projection of the dip and strike of veins of the vein type deposits (see Table 4), the 


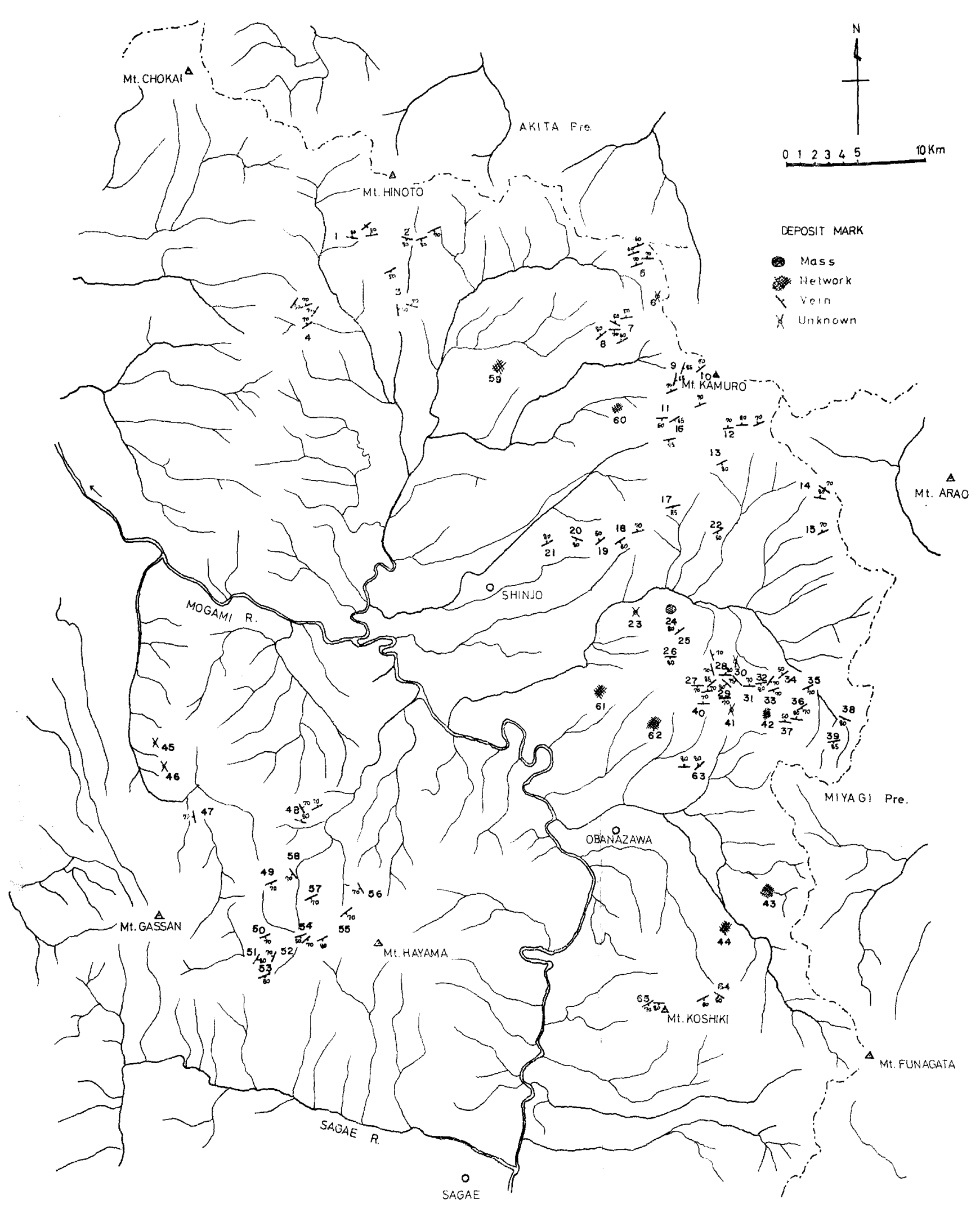

Fig 3. Distributional map of the ore deposits surrounding the Shinjo Basin.

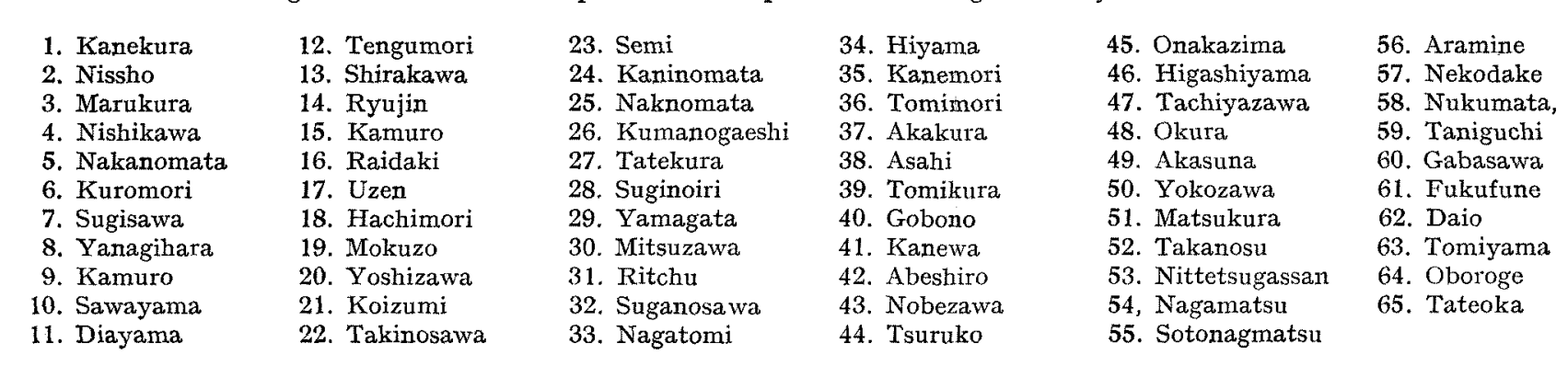

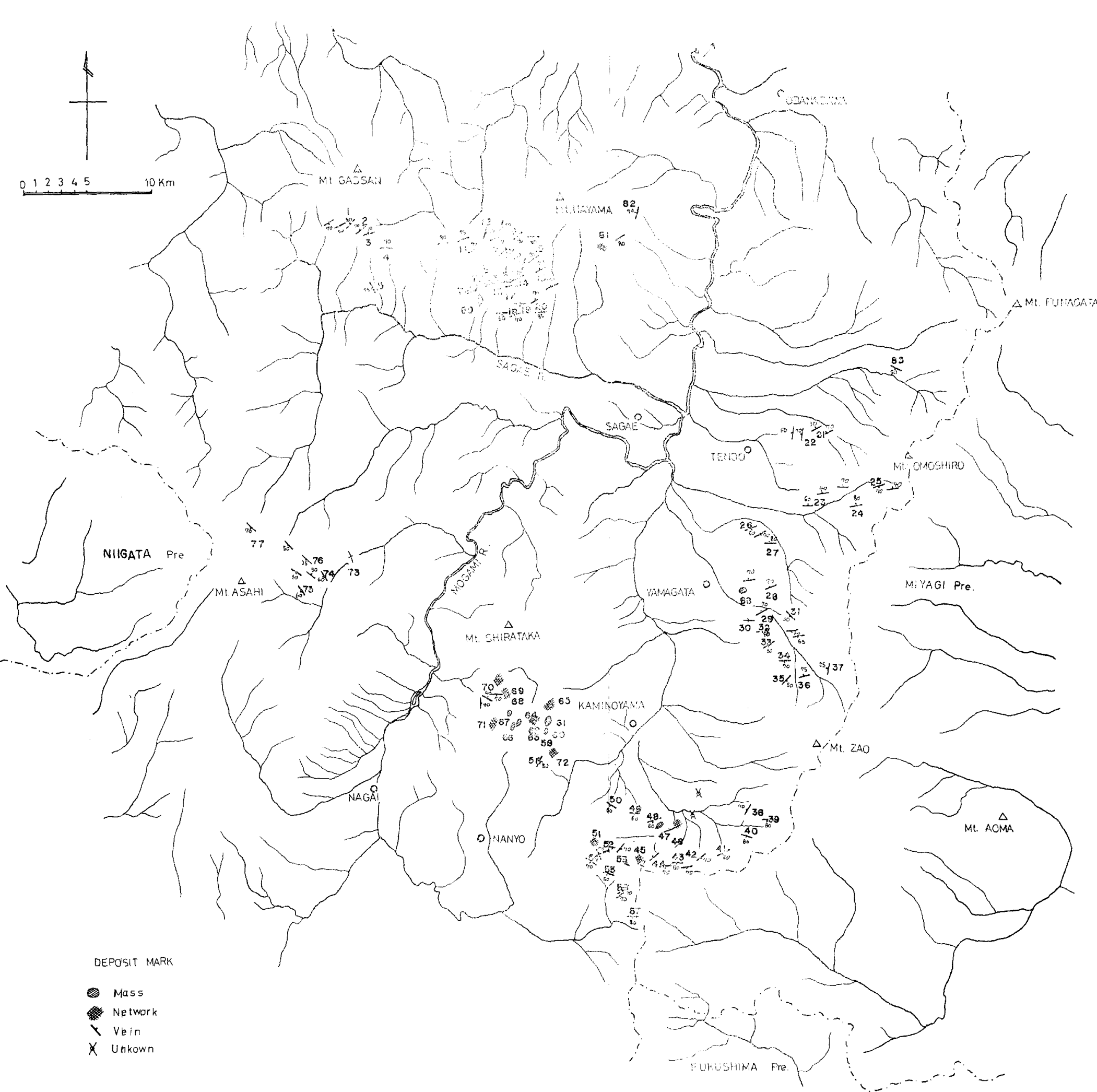

Fig. 4. Distributional map of the ore deposits surrounding the Yamagata Basin.

1. Showagassan
2. Dennosuke
3. Fudodaki
4. Ogiadara
5. Hondoji
6. Sachiu
7. Murayama
8. Miharu
9. Wakayama
10. Hirana
11. Takaho
12. Mitata
12. Mitate

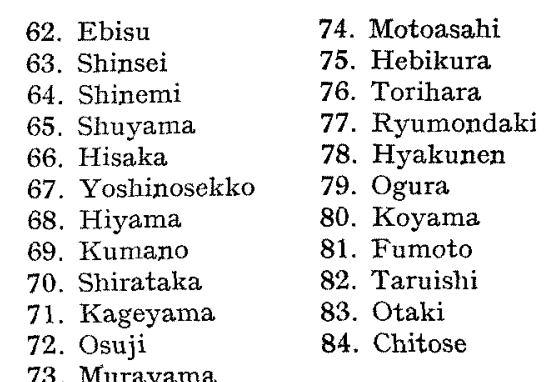



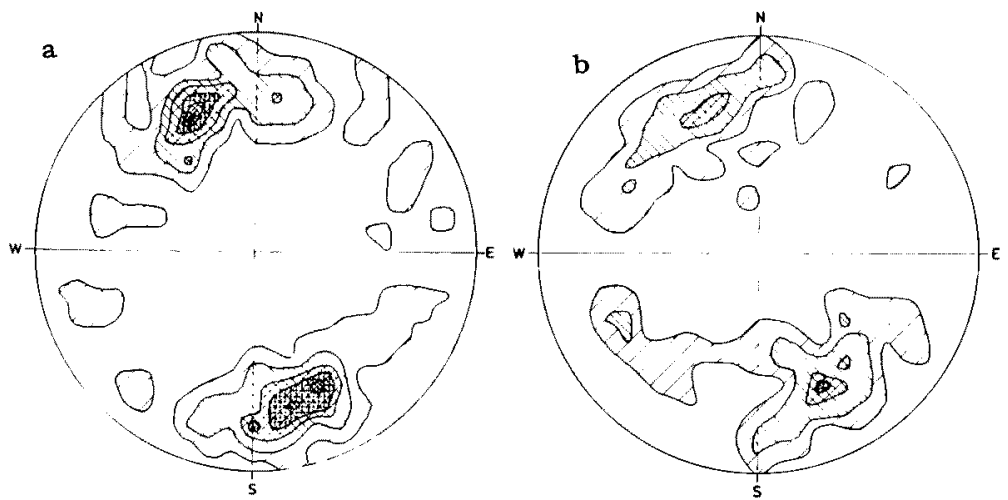

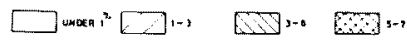

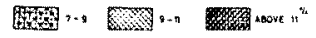

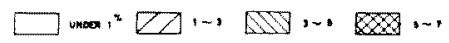

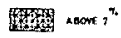
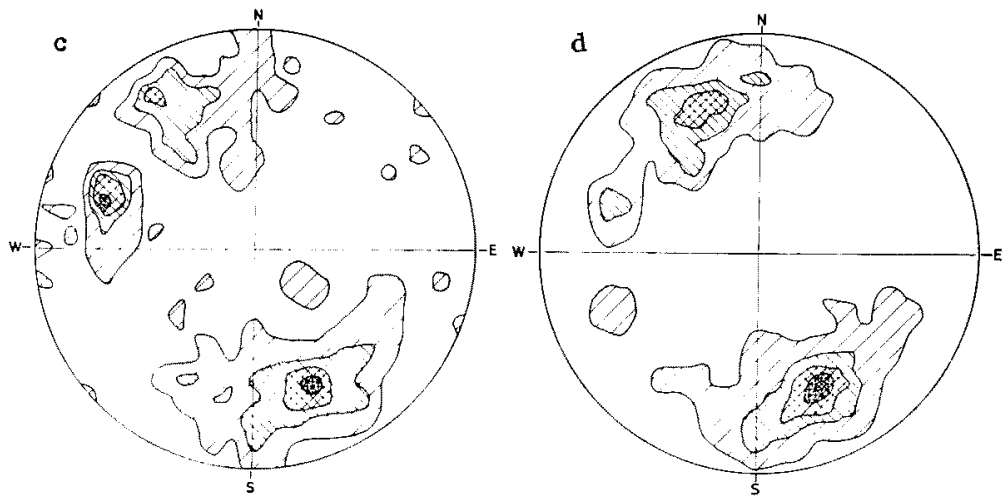

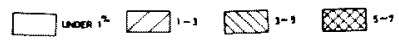
3xin

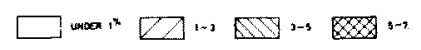

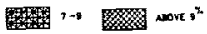

Fig. 5. Diagrams showing vein dirrections. a : Northern to eastern of Shinjo Basin b : Mt. GassanHayama c: Mt. Funagata-Zao d: All veins in the studied area

most abundant of 93 veins in northern and eastern Shinjo Basin are those trending $\pm \mathrm{N} 64 \mathrm{E}$; of the 115 veins in the Ou Backbone Range, the most abundant are those trending $\pm \mathrm{N} 66 \mathrm{E}$; and of the 92 veins in the Gassan-Hayama Mountainland area within the boundary between the two Basins, the most abundant are those trending $\pm N 62 \mathrm{E}$. Considering the 300 veins present within these three areas, the most abundant are those trending $\pm \mathrm{N} 64 \mathrm{E}$; and next in abundance 


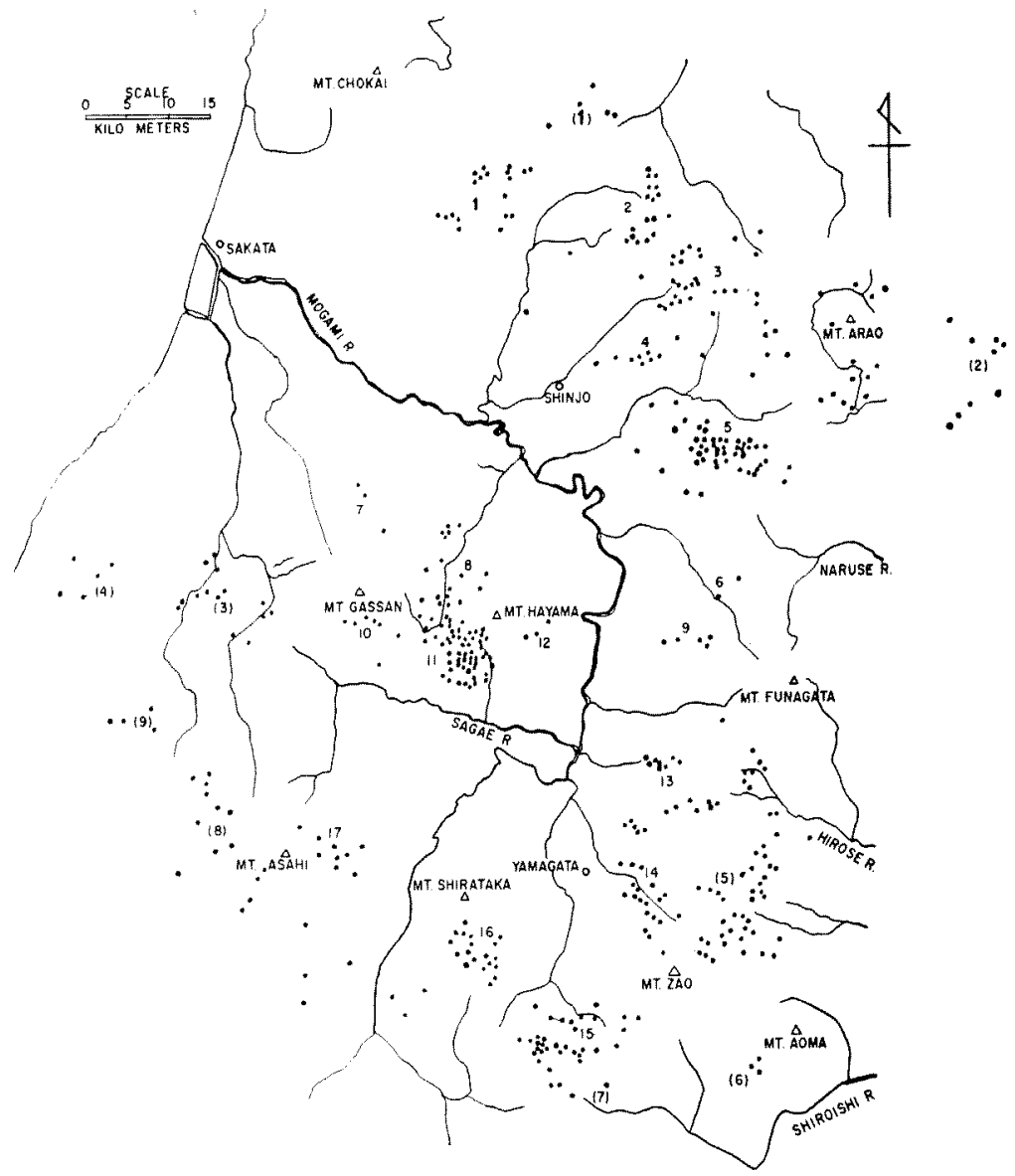

Fig. 6. Distributional map of the ore deposit regions. D. G. = Deposit groups

Shinjo Basin: 1. Arisawayama D. G. ; 2. Toyasawayama D. G; 3. Tengumori D.G. ; 4. Hachimori D.G.; 5. Akakura D. G. ;
6. Nobezawa D. G.
7. Kokuzo D. G. ;
8. Hijiori
D. G. ;

9. Koshikidake D. G. :

Yamagata Baein: 10. Jizomoriyama D. G. ; 11. Nishiyama D. G. ; 12. Fumoto D.G. ; 13. Omoshiroyama D. G. ; 14. Hozawa D.G. 15. Akayama D.G.; 16. Yoshino D.G. ; 17. Asahi D. G;

Outside of these Basins: (1) Innai D.G. ; (2) Hosokura D.G. ;

(3) Obari D. G; (4) Nezugaseki D. G. ; (5) Kawasaki D. G. ;

(6) Fukuoka D.G. ; (7) Miomote D.G. ; (8) Oizumi D. G. ; 


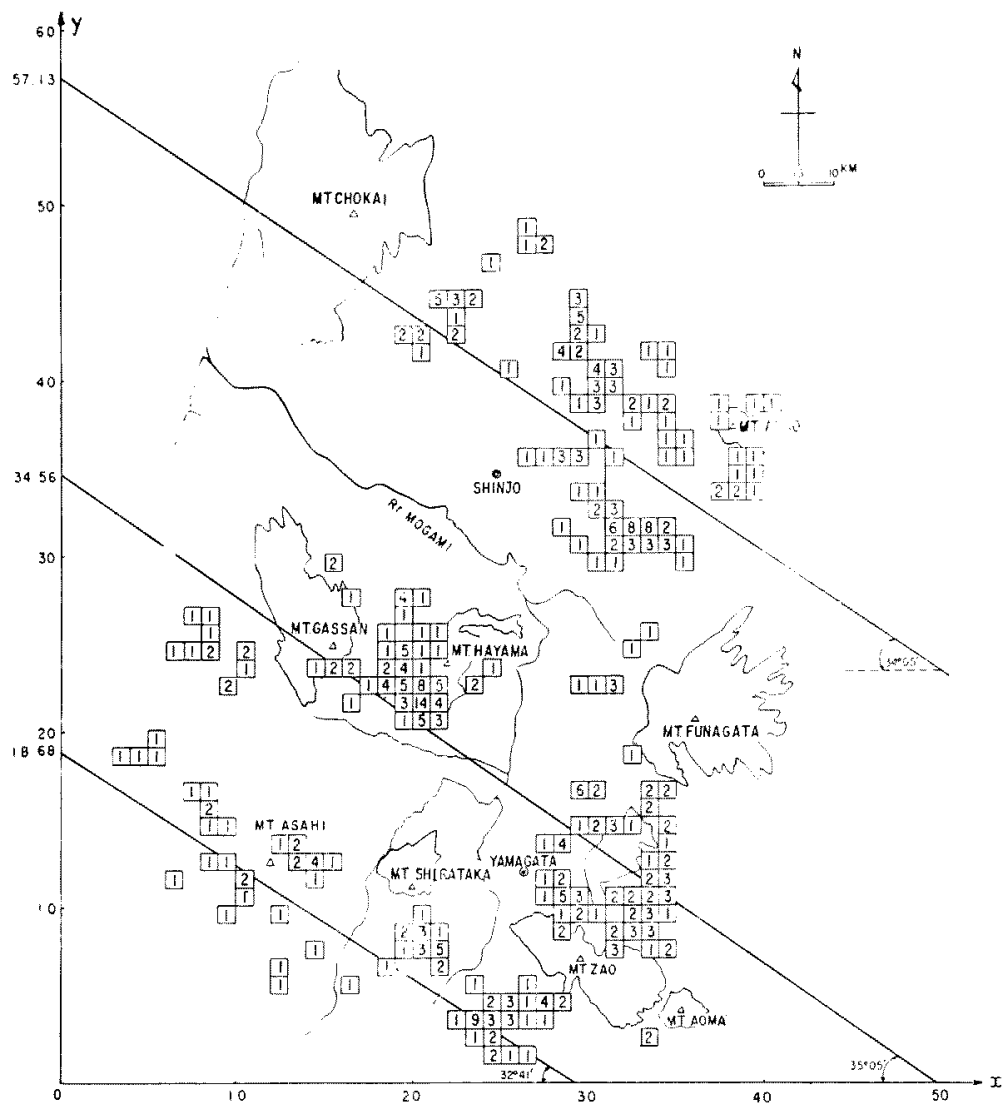

Fig. 7. General direction of distribution of ore deposits.

are those trending $\mathrm{N} 70 \pm 90 \mathrm{E}$. The NNW-SSE trending veins are notably very scarce in any part of the two basins.

The more than 300 ore deposits within the Shinjo Basin and the Yamagata Basin may be grouped into three, namely: 1) those occurring the area from northern Shinjo Basin to northeastern Shinjo Basin, 2) those occuring in the area from the vicinity of Gassan-Hayama Volcano to eastern Yamagata Basin, and 3) those occurring in southern Yamagata Basin. The general direction of distribution of the ore deposits within each of these groups, as calculated by the method of least squares with the multinominal formula, $y=a_{1} x+a_{0}$, are shown in the table 6 . This was processed in the NEAC-2230 type electronic computer. 
Table 5. The distribution of ore districts according to ore region.

\begin{tabular}{|c|c|c|}
\hline No. & Ore Region & Ore Districts \\
\hline 1 & $\begin{array}{l}\text { Northern to } \\
\text { Eastern Shinjo } \\
\text { Basin }\end{array}$ & $\begin{array}{l}\text { 1. Arisawayama, 2. Toyazawayama 3. Ten- } \\
\text { gumori, 4. Hachimori, 5. Akakura, (1) } \\
\text { Innai }\end{array}$ \\
\hline 2 & $\begin{array}{l}\text { Gassan-Hayama } \\
\text { Volcano Vicinity } \\
\text { to eastern Ya- } \\
\text { magata Basin }\end{array}$ & $\begin{array}{l}\text { 6. Nobezawa, 7. Kokuzoyama, } \\
\text { 9. Koshikidake, Hijiori } \\
\text { yama, 10. Jizomoriyama, 11. Nishi- } \\
\text { Hozawa, (3) Yakuwayama, (5) Kawasaki, } \\
\text { Fukuoka }\end{array}$ \\
\hline 3 & $\begin{array}{l}\text { Southern Yama- } \\
\text { gata Basin }\end{array}$ & $\begin{array}{l}\text { 15. Akayama, 16. Yoshino, 17. Asahi, (7) Shi- } \\
\text { chigashiku, (8) Mimote, (9) Otori }\end{array}$ \\
\hline
\end{tabular}

Table 6 . The result of calculations.

\begin{tabular}{c|c|c|c}
\hline Group No. & $\mathrm{y}=\mathrm{a}_{1} \mathrm{x}+\mathrm{a}_{0}$ & $\theta=\tan ^{-1} \mathrm{a}_{1}$ & Direction \\
\hline 1 & $y=-0.6768 x+57.13$ & $a n^{-1}-0.6768=-34^{\circ} 05^{\prime}$ & $\mathrm{N} 56^{\circ} \mathrm{W}$ \\
\hline 2 & $y=-0.7022 x+34.56$ & $\tan ^{-1}-0.7022=-35^{\circ} 05^{\prime}$ & $\mathrm{N} 55^{\circ} \mathrm{W}$ \\
\hline 3 & $y=-0.6144 x+18.68$ & $\tan ^{-1}-0.6144=-32^{\circ} 41^{\prime}$ & $\mathrm{N} 57^{\circ} \mathrm{W}$ \\
\hline
\end{tabular}

The result of these calculations shows that the general direction of distribution of the ore deposits within the 3 groups is $N 56 W_{ \pm}$ 1 degree. This direction makes a 60 degree angle with the major structural line trending $\pm N-S$. Also, it makes an angle of 120 degrees with the previonsly mentioned most abundant direction of ore veins as gathered from sterengraphic projections, which is N64E \pm 2 degrees. Thus, the major structural line $( \pm \mathrm{N}-\mathrm{S})$ of both basins bisects the 120 degres angle made by the general direction of distribution of ore deposits $(\mathrm{N} 56 \mathrm{~W} \pm 1)$ and the direction of the most abumlan veins $(\mathrm{N} 64 \mathrm{E} \pm 2)$; and these three directions make an angle of 60 degree with one another. The ore veins are then arranged like a flight of wild geese, side by side with one another, with the general direction of distribution of ore deposits as the axis (Campbell, 1958).

The N56W line along which the 5 ore districts in the northeastern quadrangle of Shinjo Basin are distributed, passes through the southern part of Kaneyama Town, about 15 kilometers north of Shinjo City, and extends northwestward to the southern foot of Chokai Volcano and southeastward to Sakaida Hill, east of Akakura 
Basin. It runs parallel to and along the southern side of the mountain range separating Yamagata and Alita Prefectures which topographically changes to a plain. The 5 ore districts here, which includes the Akakura district are distributed along both sides of this line.

In the area from Gassan and Hayama Volcanoes to the eastem part of Yamagata Basin, another line trending N55W connects 9 ore districts and passes through Sagae City, about 15 kilometers north of Yamagata City, and extends northwestward to the southern foot of Gassan Volcano and southeastward ot the Futaguchi Hill of Ou Moutain Range. These 9 ore districts, which includes the Nishiyama district are distributed on both sides of this line.

In between and flowing parallel to these two general directions is the Mogami River, which is considered a fault river. Thus, it is believed that these two alignments of ore deposits are related to tectonics.

In the southern part of Yamagata Basin, the N57W line connecting 3 ore districts passes through Iwabe Mountain, in between Kaminoyama City and Nanyo City in the southern and of Yamagata Basin, and extends northwestward to the southern foot of Oasahi Mountain and southeastward to the southern part of Kaneyama Hill. This general direction is parallel to the northern foot of the mountain range in between Yamagata and Yonezawa Basins. The northern part of this mountain range is bordered abruptly by the Yamagata Basin plain. The 3 ore districts here, which include the Yoshino district, are situated along both sides of this line.

In general, the ore deposits in both the Yamagata Basin and Shinjo Basin, are distributed in zones whose axes are the said three general directions or lines. These axes are believed to be the suitable tectonic zones for mineralization.

Localization of the ore deposits is mainly controlled by geological structures, but the roles of the kind of country rock and degree of alteration are also appreciable (Schneiderhöhn, 1952). In general fissures are more developed within shale and mudstone than within tuffaceous rocks, and especially when they are silicified the fissures are developed to the utmost (Hulin, 1948). This fact is well exhibited in the Koyama Mine. When the tuffaccous rocks are argillized, their roles become important in the formation of bonanzas in clay zones, as cap rock preventing the advance and dissemination of ore solutions (Lindgren, 1933). This is well exhibited in the 
Miharu and Takahi Mines of northern Yamagata Basin.

The deposition of each of these massive type, network type, and vein type deposits are all structurally controlled by faults, fissures and crushed zones. Accordingly, the massive type ore deposits usually occupies the points where the aggregate of these structures is densest and this is surrounded by network type deposits, which, in turn is surrounded by vein type deposits (Hulin, 1929; Lewis, 1955). This is best shown by the Yoshino massive type deposit region of western Yamagata Basin. Here, the Ebisu, Daikoku, Hotei, Shinsei and Fukuju massive type ore deposits are surrounded by the network type deposits of Shuyama, Shirataka, Kumano, Kageyama, and Shinmei; and further these are surrounded by the vein type deposits of Shirogane, Oitama, Minamizawa and many others.

This transition of types of ore deposits also occurs in the vertical direction. For example, in the Bonten deposit of Koyama Mine, Nishiyama Ore District and in the Hisaka deposit of Yoshino Ore District, the massive type ore bodies gradually becomes network type downward and, further downward, it grades to vein type (Newhouse, 1942)

These metallic ore deposits of both basins are almost wholly deposited within the Basement granitic rocks and the formations earlier than the later stage of the Miocene. The faults and fissures which provided the routes of the ore solutions bringing about these mineralizations, were developed during the period from the Onnagawa stage to the Funakawa stage. During this period, uplift of the Basement was active and igneous activity brought about the "Tertiary granite", dacite, rhyolite and dolerite intrusives. Therefore, the stage of formation of the ore deposits corresponds to the Funakawa Stage. The Furuguchi formation of Shinjo Basin and the Ogureyama formation of Yamagata Basin are considered deposited during the later stage of the Miocene (Takeuchi, 1961). The volcanic activity and the uplift of the region, which started after the later stage of the Miocene and operative throughout the Pliocene, is still operative at present. Considering the distribution of ore deposits and the localization of hot-springs, the volcanic activity at this period appears to have a causal relationship with the igenous activity during the later stage of the Miocene which brought about the formation of the mineral deposits (Lindgren, 1933; Cloos, 1939 ; Lewis, 1955). 


\section{ACKNOWLEDGMENT}

The author extends profound gratitude to Professor Tsunehiko Takeuchi of Tohoku University, who gave hearty guidance in the organization and publciation of this report. Sincere thanks are also due to Professor Yushi Funayama of the Miyagi University of Education and to Assistant Professor Kazuo Taguchi of Tohoku University who gave invaluable instructive advices. The author also avails of this opportunity to offer cordial thanks to each and everyone of the many mining firms, who extended cooperation in the field.

\section{REFERENCES}

Bayly, M.B. (1964), A theory of similar folding in viscous materials, Am. Jour. Sic., 262, $753 \sim 766$.

Billings, M.P. (1962), Structural geology, Prentice-Hall, New York. Campbell, J.D. (1958), En echelon folding, Econ. Geol., 53, 448 472.

Cloos, H. (1930), Zur Experimentellen Tektonik, Naturwissenschaften, 18 Jahrg., Heft 34 .

- (1939), Hebung, Spaltung, Vulkanismus, Geologische Rundschau, Band 30, Zwischenheft $4 \mathrm{~A}$.

Currie, J.B., Patnode, H.W, and Trump, R.P. (1962), Development of folds in sedimentary strata, Geol. Soc. Am. Bull., 73, 655 674.

Emmons, W.H. (1935), On the origin of certain system of orebearing fractures, Trans. A.I.M.E. 115, $9 \sim 35$.

Fujioka, K. (1958), Stratigraphy of so-called "green tuff" formation, Jour. Soc. Min. Geol. Jap., 8, 49.

Funayama, Y. (1961), The geology and geological structure in the marginal area of the Yamagata basin, with special reference to the ore deposits, Yamagata Prefecture, Japan, Sci. Rept. Tohoku Univ., Ser. III, 7, $199 \sim 291$.

- (1962), Notes on the stratigraphic nomenclature concerning the borderland of the Yamagata basin, Yamagata Prefecture, Northeast Japan, Jour. Tohoku Min. Soc. 9, 15 21.

Hatai, K., Funayama, Y. (1956), Remarks on the sedimentary structures observed in the older Miocene Marine Formations developed in NishiMurayama and Nishi-Oitama districts, Yamagata Prefecture, Northeast Honshu, Japan, Jour. Geol. Soc. Japan, Tokyo, 62, $139 \sim 145$.

Hayakawa, N. (1950), Ore deposits in the lower formation of the Tertiary sediments at Ou-Mountainland, Iwate Prefecture, Part 1. On the types of metallic ore deposits, Jour. Jap. Asso. Min. Petr. Econ. Geol., 34, $113 \sim 122$.

Hulin, C.D. (1929), Structural control of ore deposits, Econ. Geol. 24, $15 \sim$ 49. 
(1948), Factors in the localization of mineralzied districts, Trans.

A.I.M.E., $178,36 \sim 57$.

Ichimura, T. (1958), Hotspring Geology in Yamagata Prefecture, Sci. Hotsp. $9,27 \sim 29$.

Ikebe, Y., Ishiwada Y., Kawai, K. (1966) Tertiary formation and hydrocarbon deposits in Northeast Japan, Memo. Trea. Prof. Matsushita, S., Kyoto.

Ishii, K., Ueda, Y. (1955), Tertiary granite in the northeastern Japan I (Granites occured along the Okoku line, Waga district,) Jour. Jap. Assoc. Min. Pet. Econ. Geol., 39, 43 58.

Kato, T. (1951), Petrogenetic considerations on the lower formation in the oil-field of northeastern Japan (II) - On the Tertiary stallineholocry intrusives in the eastern part of the Shinjo Basin, Jour. Jap. Asso. Min. Pet. Econ. Geol., 35, $91 \sim 106$.

Kawano, $Y^{+}$, Ueda, Y. (1966), K-A dating on the igenous rocks in Japan (VI) Granitic rocks in northeastern Japan, Jour. Jap. Asso. Min. Pet. Econ. Geol., 56, 41 $\sim 55$.

Konda, T. (1951), On the intrusive sheet developed around Shinjo Basin, Jour. Jap. Asso. Min. Pet. Econ. Geol.. 35, $11 \sim 15$.

- (1959), On the Segregation Veins in the Tertiary Dolerites of the Dewa Hilly Land, North-eastern Japan, Geol. Soc. Japan. 65, $374 \sim 384$.

Lewis, D.V. (1955), Relationships of ore bodies to dikes and sills, Econ. Geol., 50, $495 \sim 516$.

Lindgren, W. (1933), Mineral deposits, McGraw-Hill, New York.

Maki, S., Yazaki, K., Hirakawa, T. (1966), Exploration for Helium Resoruces in Yamagata Prefecture, Japan, Bull.Geol. Sur. Jap., 17, 23 43.

McKinstry, H.E. (1941), Structural control of ore deposition in fissure veins, Trans. A.I.M.E., Vol. 144, $65 \sim 95$. (1955), Structure of hydrothermal ore deposits, Econ. Geol. 50th Anni. Vol., Part 1, $170 \sim 225$.

Miyabe, N. (1940), Results of rerunning the line of levels linking Shibata with Taria, Proc. Imp. Acad. 16, 178 181 .

Newhouse, W.H. (1931), Some relation of ore-deposits and folded rocks, Trans. A.I.M.E., 90, $224 \sim 240$.

- (1940), Openings due to movement along a cruved or irregular fault plane, Econ. Geol., 35, 445 464.

Oizumi, N. (1967), Geology and ore deposits of Shirataka mine, Yamagata Prefecture, Jour. Jap. Asso. Min. Petr. Econ. Geol., 58, $31 \sim 38$. (1967), Geology and ore deposits of Takagami mine, Yamagata Prefecture, Jour. Jap. Asso. Min. Petr.

Orimoto, S. (1964), Geology of the Nissho mine, Yamagata Prefecture, with special reference to the Tertiary granitic rocks, Jour. Soc. Min. Geol. Jap., 14, 248 260, $299 \sim 307$.

Otsu, H. (1956), Mineralization and fissure system in the central mining district of Yamagata Prefecture, with specital reference to genesis of epithermal veins. Min. Geol., 6, 13 24, 6, 67 79. 
Otsuka, Y. (1942), Geological structure of Japan.

Riedel, W. (1929), Das Aufquellen geologischer Schemlzmassen als plastisohen Formänderungavorgang, Neues Jahrbuch der Mineral ogie, Beilagbeand 67, Abt. B, 151.

Schmitt, H. (1951), Origin of the epithermal mineral deposit, Econ. Geol., 44, $191 \sim 200$.

Schneiderhöhn, H. (1949), Erzlagerstätten, 22.

(1952), Genetische Legerstättengliederung auf geotektonicher Grundlage (Stuttgart), Neues Jahrbuch Mineralogie, Mh. 2u. 3, 17 89.

Taguchi, K. (1960), On the lower formations of the Neogene Tertiary in the Dewa hilly land, Jour. Geol. Soc. Jap. Tokyo, 66, $102 \sim 113$.

(1962), Basin architecture and its relation to the petroleum soruce rocks development in the region bordering Akita and Yamagata Prefectures and the adjoining areas, with the special reference to the depositional environment of petroleum soruce rocks in Japan, Sci. Rep. Tohoku Univ., Ser. III, 7, 293 342 .

Takahashi, H. (1962), Geology and ore deposits in the Akakura area, Mogami group, Yamagata Prefecture, Bul. Geol. Sur. Jap. 13, 67 74.

Takeuchi, T.,Sugaki, A., Suzuki, T. and Abe, H. (1960), Ore deposits of the Ohori mine, Yamagata Prefecture, Japan, Jour. Soc. Min. Geol. Jap., $10,8 \sim 28$.

(1961), Ore mineralizations related to the Igneous activities in Northeastern Japan, Jour, Soc. Min. Geol. Jap. 11, 17 21 .

-, Funayama, Y., Yamaoka, K. and Abe, H. (1965), Occurrence of ferberite from Obanazawa mine, Yamagata Prefecture, and its significances in the mineralization in the green tuff region, Jour. Jap. Asso. Min. Petr. Econ. Geol., 54, $113 \sim 126$.

Taneda, S. (1944), Studies on volcanoes in Japan (1), Lateral pressure at present, Jour. Jap. Asso. Min. Pet. Eco. Geol, 32, $22 \sim 40$.

Watanabe, M. and Sugaki, A. (1950), Ore deposits in Nishiyama village, Nishimurayama group, Yamagata Prefecture, Rept. Min. Exper. Sta. Jap. No. 9 . and $-(1950)$, Ore deposits in Yoshino village, Higashioitama group, Yamagata Prefecture, Rept. Min. Exper. Sta. Jap. No. 10.

Willis, B. and Willis, R. (1934), Geologic structures, McGraw-Hill, New York. 


\title{
新庄・山形両盆地に胚胎する金属鉱床の成因的研究
}

\author{
大泉 製 次
}

摘 要

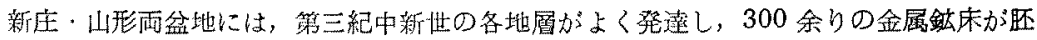
胎している。これらの鉱床を，新庄盆地北緣〜東縁，新庄・山形雨盆地境界，山形盆地南

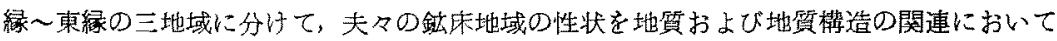
究明し, 分析し, 且つ整理した。

研究の結果，鉱床分布の総合的方位と，脈状鉱床の走向方位の罠大密度方位とが，三つ

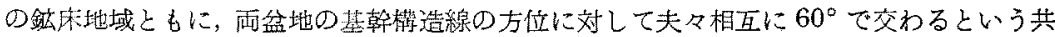
通の覞則性を州納することを得た。

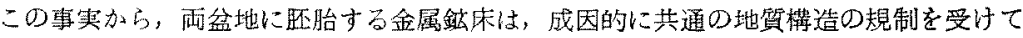
生成したものと涍られる。 